\title{
ECOSYSTEM HEALTH, HUMAN EXISTENCE, AND BIO-CAPACITY DEFICIT: THE ETHICAL RELATIONSHIP
}

\author{
Choy Yee Keong \\ Graduate School of Economics, Kyoto University, Kyoto, Japan.
}

\begin{abstract}
This article reviews the contribution of ecosystem services to human existence, followed by a quantitative investigation into the state of our planet with specific reference to greenhouse gas emissions and global warming. This synthesis reveals that despite the fact that the global community has undertaken a wide range of environmental conservation measures to protect the ecological resilience of the ecosystems for the sake of sustaining long-term human existence, ecological degradation remains a serious problem across the globe. It is concluded that while the establishment of environmental protection measures is important to promote ecological sustainability, what is needed is a new view of human relationship with nature that will ensure ethical behaviour towards it. The way forward is to encourage the cultivation of a harmonious human-environment relationship based on the ethics of human-nature relations.
\end{abstract}

Keywords: anthropocene, bio-capacity deficit, ecosystem health, environmental ethics, global warming, human existence.

\section{INTRODUCTION}

Humankind has long recognized the importance of preserving the ecological health of ecosystems because of the critical services such as carbon sequestration and climate regulation they provide to sustain human life. Indeed, man's continued existence hinges on maintaining ecosystem health. However, sustainable use and management of ecosystems persist as one of the major challenges facing the global community today.

In addressing this challenge, the United Nations has, for the past 40 years, through its continuous and unrelenting efforts, convened many international conferences such as the Stockholm Conference (1972), the Rio+20 Conference (2012), and the High-Level Summit on the Millennium Development Goals (2013) to call on the international community to protect the earth's ecosystems. In response, virtually all countries across the globe have undertaken efforts to streamline their development path for a wiser use of our natural systems.

However, it is obvious that the world is still pursuing a chaotic path of development characterized by ever-increasing scales of production and consumption, and unrestrained expropriation of ecological resources. As a case in point, waves of industrialization in the emerging Asian economies, especially China, continue to overburden the atmospheric, land and ocean carbon sinks, leading to bio-capacity deficit and threatening long-term human existence. While bio-capacity measures the bio-productive efficiency of ecosystems, a biocapacity deficit is identified as a situation when the ecological footprint exceeds the productivity or regenerative capacity of the natural environment, Schaefer et al. [1], Sanders and Wood [2]. 
This article contends that one of the main factors contributing to the unsustainable use of nature despite continued international and national environmental protection initiatives is the general lack of a holistic understanding of the contribution of ecosystem services to human existence, and how human actions lead to adverse environmental change detrimental to human survival in the long-term.

Against this backdrop, the article will first review knowledge on the relationship between human existence and ecosystem health, highlighting what biodiversity can do for us. The discussion will focus on the importance of interconnectedness of life in nature. This is followed by a quantitative investigation on the state of our planet with specific reference to greenhouse gas emissions and global warming. While global environmental protection initiatives as preached by the United Nations are needed to promote ecological sustainability, what has been missing is a radically new and ethical perspective of the human-nature relationship. The last part of the article explores the cultivation of a harmonious human-environment relationship, which is likely to ensure improved human behaviour towards nature.

\section{ECOSYSTEM SERVICES AND LONG-TERM SOCIO-ECONOMIC PROGRESS}

An ecosystem, defined as the sum total of surrounding things, conditions, and influences, refers to an ecological unit in a specific area. It comprises biotic components (living components), including humans and the biodiversity of other living organisms, and abiotic components (non-living components) such as the physical environment and conditions. The web of life within the ecosystem is not only interconnected but is also interdependent. If we remove a species, especially a keystone species, from the system, for example, we may destabilize the whole ecological system. A keystone species is a plant or animal that plays a crucial role in maintaining the organization, diversity or resilience of the ecological communities. The removal or disappearance of a keystone species from an ecosystem where it occurs will lead to the disappearance of a wide range of species resulting in the eventual collapse of the whole ecosystem, Mills et al. [3].

Some of the most important ecosystem services that sustain human life are shown in Table 1.

Table 1 shows clearly that ecosystems are multifunctional systems which provide humanity with a range of critical life-supporting services. They may be classified as keystone natural systems because ecological disturbances caused by over-exploitation or unsustainable resource use practices will threaten their, capacity to retain their vital functions, services and controlling mechanisms which human beings depend on to support their continued existence. Ecological health and human existence are integrally linked. It is worth noting that while ecosystems can survive by themselves without human species, human beings cannot survive without the ecosystems.

To provide an analytical scaffolding for the subsequent analysis, it is relevant to highlight that while all the keystone natural systems, as listed in Table 1, play important roles in regulating greenhouse gases, it is the oceans that constitute the largest carbon sink on earth. The oceans exchange large amounts of carbon dioxide $\left(\mathrm{CO}_{2}\right)$ with the atmosphere based on two main processes, namely, the physical carbon pump and biological carbon pump, HardmanMountfor et al. [8].

The physical carbon pump is a natural cycle which draws $\mathrm{CO}_{2}$ into the deep ocean through downwelling currents from some colder and more biologically active parts of the ocean. The dissolved $\mathrm{CO}_{2}$ is released back to the atmosphere through upwelling currents from the generally warmer and less biologically active parts of the deep ocean. When dissolved $\mathrm{CO}_{2}$ is 
180 Environmental and Economic Impact on Sustainable Development

Table 1: Ecosystem services: a summary.

Keys to De Natural System/Resources

Regulating services:
Regulating the Earth's climate based on a process known as
bio-sequestration- a process of capturing and storing carbon
dioxide $\left(\mathrm{CO}_{2}\right)$ from the atmosphere through photosynthesis. The
Amazon tropical rainforests in Brazil and the Borneo rainforests in
Southeast Asia are two of the world's most important green lungs in
sequestrating $\mathrm{CO}_{2}$ or regulating global climate change.
Provisioning, cultural and amenity services:
(a) 1.6 billion rural people worldwide depend on forests to some
extent for their socio-economic sustenance
(b) 1 billion out of 1.2 billion extreme poor in the world depend on
forest resources for all or part of their livelihoods
(c) $300-350$ million people worldwide are highly dependent on
forests to meet their needs
(d) Indigenous culture and socio-economic systems are closely
related to forest resources
(e) Tropical rainforest ecosystems provide recreation and aesthetic
appreciation to human societies. Such services may improve mental
health and inspiration.
Other life-supporting provisioning services:
Apart from serving as a supply base for production input and hu-
man needs such as food, water, raw material, the tropical rainforests
also represent a rich reservoir for medical plants and herbs: (a)
120 prescription drugs sold worldwide today derived directly from
rainforest herbal or medical plants, (b) More than $2 / 3$ of all medi-
cines with cancer fighting properties come from rainforest herbal
or medical plants. (c) 3.5 billion people in the developing countries
rely on plant-based medicine for primary health care.
Regutiong and

Lakes, streams and rivers

Atmosphere

Wetlands

\section{Functions}

Regulating services:

Regulating the Earth's climate based on a process known as dioxide $\left(\mathrm{CO}_{2}\right)$ from the atmosphere through photosynthesis. The Amazon tropical rainforests in Brazil and the Borneo rainforests in Southeast Asia are two of the world's most important green lungs in sequestrating $\mathrm{CO}_{2}$ or regulating global climate change. extent for their socio-economic sustenance

(b) 1 billion out of 1.2 billion extreme poor in the world depend on forest resources for all or part of their livelihoods

(c) 300-350 million people worldwide are highly dependent on

(d) Indigenous culture and socio-economic systems are closely

elated to forest resources

e) Tropical rainforest ecosystems provide recreation and aesthetic appreciation to human societies. Such services may improve mental health and inspiration.

Other life-supporting provisioning services:

Apart from serving as a supply base for production input and human needs such as food, water, raw material, the tropical rainforests also represent a rich reservoir for medical plants and herbs: (a) 120 prescription drugs sold worldwide today derived directly from rainforest herbal or medical plants, (b) More than 2/3 of all medicines with cancer fighting properties come from rainforest herbal rely on plant-based medicine for primary health care.

Regulating and supporting services:

Serve as a waste sink for waste water discharges or $\mathrm{CO}_{2}$ emissions.

Regulating and supporting services:

Serves as a waste sink for air emissions or pollution.

Regulating and supporting services:

Serve as a waste sink for carbon: wetland stores carbon within live and peat plant biomass instead of releasing it to the atmosphere as carbon dioxide. They also play an important role in filtering fresh water by removing various chemical and potentially toxic materials such as heavy metals like cadmium and lead. Wetlands also perform the function of regulating and stabilizing water runoff/supply. They also store precipitation and surface water and then slowly release the water into associated surface water resources. 
Table 1: (Continued)

\section{Keys to De Natural System/Resources \\ Functions}

Regulating and supporting services:

Peatland is a carbon-rich natural resource which contained twice as much carbon stock as the entire forest biomass of the world. The peat swamp forests of Central Kalimantan in Indoensia, for Peat lands $\quad$ example, store the largest amount of carbon in Borneo: about 6.4 gigatonnes $(\mathrm{GtC})$ or about 10 times that of the UK's total greenhouse gas emissions in 2005. Also, a volume of peat soil consists of $90 \%$ of water and this helps to protect against floods after heavy rainfall.

Regulating and supporting services:

Protect against storms, flooding and erosion by dissipating wave Coastal ecosystems energy and trapping sediments (for example, coastal forests, coral reefs, sand dunes and wetlands protect two-thirds of the US coastline from hazards including hurricane storm surges).

Regulating and supporting services:

Protect against storms, flooding and erosion by dissipating wave Oceans energy and trapping sediments (for example, coastal forests, coral reefs, sand dunes and wetlands protect two-thirds of the US coastline from hazards including hurricane storm surges).

Note: compiled by the author from various sources including WHO [4], Nellemann et al. [5], WWF [6], and Gewin [7], among others.

released to the surface along coastlines, the coastal ecosystems will regulate the $\mathrm{CO}_{2}$ intensity through their carbon absorption capacity. Furthermore, the ocean takes up $\mathrm{CO}_{2}$ through photosynthesis by phytoplankton (marine plants). This creates a biological carbon pump that draws a massive amount of $\mathrm{CO}_{2}$ in surface ocean water. It has been estimated that photosynthesis in the ocean surface produces about $100 \mathrm{GtC}$ gigatonnes (billion tonnes, GtC) of organic carbon per year, and some 5-15 GtC are transported to ocean depths and may stay there for thousands of years, Giering et al. [9]. However, it should be noted that the estimated rate at which phytoplankton consumes $\mathrm{CO}_{2}$ varies substantially from various studies. Nonetheless, it is indisputable that the climate regulating services provided by oceans touch the core of human existence.

The oceans' capacity to store $\mathrm{CO}_{2}$ from the atmosphere and the physical, chemical and biological processes responsible for this are vulnerable to the effects of climate change, Sabine and Feely [10] and Hardman-Mountfor et al. [8]. It may well be that increasing $\mathrm{CO}_{2}$ concentration due to unrestrained human economic activities with the resultant warming effects heats the ocean enough to slow down ocean circulation. Under this condition, water trapped at the surface becomes saturated to the point, which would slow down the capacity of the ocean to absorb $\mathrm{CO}_{2}$, Sabine and Feely [10], Riebeek [11]. Rising ocean surface temperature decreases the solubility of $\mathrm{CO}_{2}$. This will adversely affect the oceans' efficiency to draw $\mathrm{CO}_{2}$ and impact on the ocean ecosystems and marine carbon cycle, Hardman-Mountfor 
et al. [8]. Recent studies indicate that rising sea surface temperatures over the past century has caused a decline of about one percent of the global phytoplankton standing, resulting in adverse changes in atmosphere-ocean surface exchange of $\mathrm{CO}_{2}$, Toseland et al. [12], Guinder and Molinero [13].

It is thus clear that the ocean and the marine ecosystems are intimately embedded in the physical climate system where a multitude of physical, social and ecological factors combine and interact with one another in a complex manner to result in bio-capacity deficit. Within the present context, bio-capacity deficit may be defined as the inability of ecosystems to retain their functions, services and control mechanisms.

It may further be noted that despite the fact that anthropogenic environmental impairment and its adverse impacts have been discussed extensively in the past few decades, there is still a general lack of a holistic understanding on the causal links between ecosystem health and human survival. More specifically, it is the failure to come to grips with the complex causal process underlying the disruption of man's environment that has rendered the global and national environmental protection initiatives far from effective in addressing the dilemma of unsustainable development across the globe, particularly in the Asian developing region.

The Asian environmental dilemma is further aggravated by the quest for capitalist expansion and consumerist lifestyles which necessitate tapping indiscriminately into the patrimony of nature to an unprecedented extent. This exerts an ever larger ecological footprint on the regional ecosystems. The unsustainable environmental practices are also partly due to the failure to understand that human-induced ecological impacts on the ecosystems are often complex, indirect, gradual and cumulative, and are felt only after a considerable lapse of time, and ultimately to threaten long-term human existence. The next section will systematically explore the causal process of man's disruption of the natural environment with specific reference to global warming.

\section{BIO-CAPACITY DEFICIT: FROM HOLOCENE TO ANTHROPOCENE}

Fundamentally, there is a set of nine global earth threshold levels or planetary boundaries within which the 'safe and just space for humanity' lies. These are (i) climate change, (ii) biodiversity loss, (iii) nitrogen and phosphorous cycle, (iv) ocean acidification, (v) stratospheric ozone depletion, (vi) global fresh water use, (vii) change in land use, and (viii) atmospheric aerosol loading (Fig. 1). As indicated in Fig. 1, out of the nine boundaries, human beings have transgressed three, namely, climate change, biodiversity loss and nitrogen cycle due to excessive resource consumption Malm and Hornborg [14]. This produces adverse impact on the biocapacity of the ecosystems to regenerate resources and absorb waste, Rockström et al. [15], ESDN [16].

The emergence of bio-capacity deficit may best be explained by the human transgression of climate change due to unrestrained atmospheric $\mathrm{CO}_{2}$ emission. To begin with, during the pre-industrial period ( the year 1800), atmospheric $\mathrm{CO}_{2}$ concentration stabilized in the range of 260-280 ppm (parts per million by volume) for the preceding 10-12,000 years. This period is known as the Holocene which is characterized by unusually stable climate and sea level conditions, Raupach and Canadell [17], Fig. 2.

Since the industrial revolution began in the 1800 s, characterized by enormous expansion in the use of fossil fuels, the earth moved from the stable state of Holocene to the chaotic state of Anthropocene (Fig. 2). The Anthropocene is a new geological epoch characterized by massive human modification of the earth's system, primarily in the form of climate change, biodiversity loss and nutrient cycle disturbance, briefly noted above. In the Anthropocene 


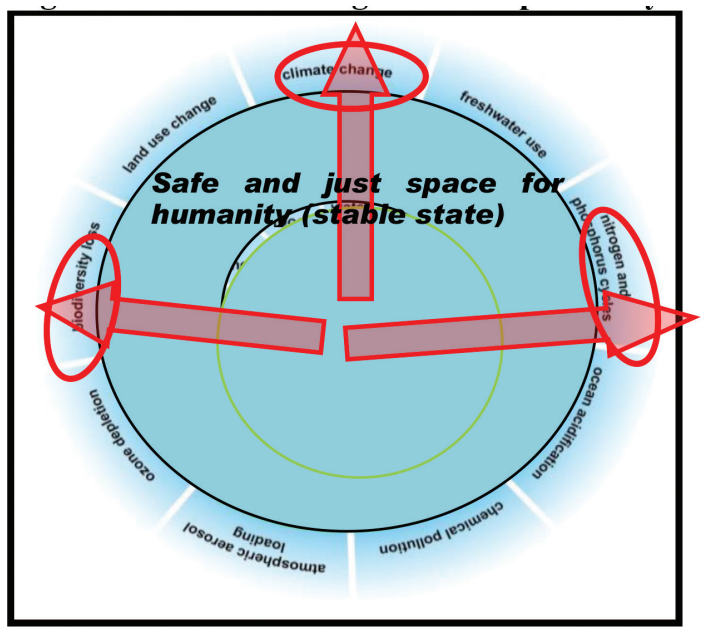

Figure 1: Human transgression of planetary boundaries.

Source: adapted from Rockström et al [15].

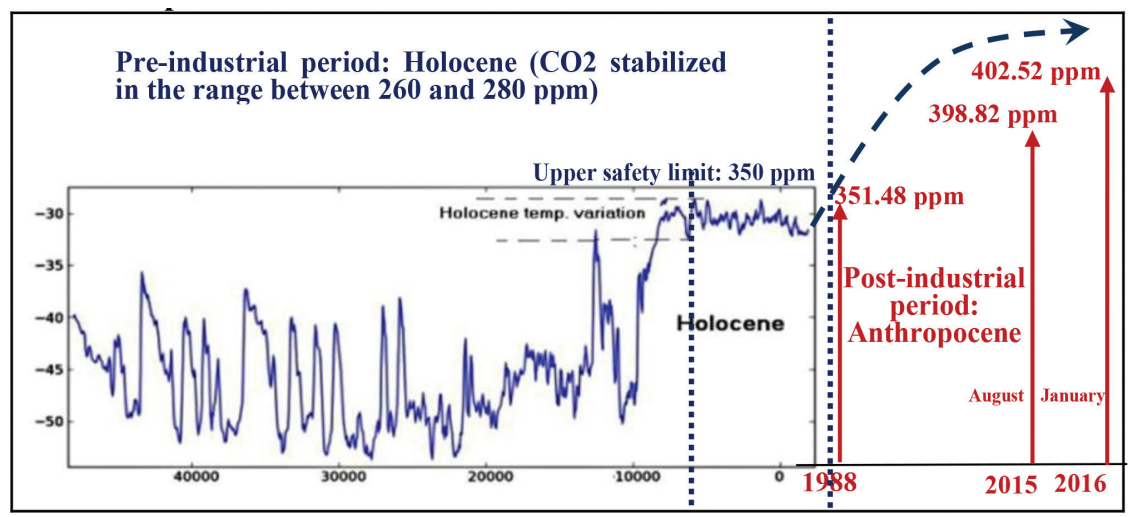

Figure 2: The changing $\mathrm{CO}_{2}$ concentration trends from Holocene period to the Anthropocene era.

Source of data: NOAA [18], CDIAC [19], CO2.Earth [20],

Note: Figure adapted from Hansen [21]

epoch, humanity ascended to biospheric supremacy as the supreme geological force capable of manipulating, modifying and transforming the earth system in the name of 'sustainable development'.

The onset of the Anthropocene epoch may best be described by climate change caused by the increasing levels of heat-trapping gases from the burning of fossil fuels. It may be noted that since the earth moved from the Holocene period to the Anthropogene era, $\mathrm{CO}_{2}$ atmospheric concentration has increased persistently from $315.98 \mathrm{ppm}$ since 1959 to $348.93 \mathrm{ppm}$ in 1987. Its concentration level crossed the upper safety limit set at $350 \mathrm{ppm}$ in 1988 and reached $398.82 \mathrm{ppm}$ in August 2015, further increasing to 402.52 in January 2016, NOAA [18], Fig. 2. 
184 Environmental and Economic Impact on Sustainable Development

Also, $\mathrm{CO}_{2}$ emission limit has far exceeded the Kyoto Protocol 1990 level at $22.7 \mathrm{GtC}$. It increased from $30.7 \mathrm{GtC}$ in 2006 to $30.6 \mathrm{GtC}$ in 2013 , and further increased to $35.95 \mathrm{GtC}$ in 2014 CDIAC [19]. Globally, China, the fastest developing country in the world, is the largest global $\mathrm{CO}_{2}$ emitter (28\% in 2013) followed by the United States (14\% in 2013) with a combined emission standard at $14.1 \mathrm{GtC}$, IEA [22], see also, $\mathrm{CO}_{2}$. earth [23].

The anthropogenic emissions of $\mathrm{CO}_{2}$ are mainly due to the burning of fossil fuel and cement production, and to a lesser extent, changing land use patterns. For example, out of the 9.795 $\mathrm{GtC}$ (35.9 $\mathrm{GtC}$ of $\mathrm{CO}_{2}$ equivalents) produced in 2014 , fossil fuel burning and cement production accounted for about $91 \%$ of the total. The source of emission is from the burning of coal (42\%), oil (33\%), and gas (19\%), cement production (6\%) and gas flaring (1\%) respectively CO2.earth [23]. From 1870 to 2014, cumulative carbon emissions totalled about $545 \mathrm{GtC}$. Of this amount, about $230 \mathrm{GtC}(42 \%) 155 \mathrm{GtC}(28 \%)$ and $160 \mathrm{GtC}(29 \%)$ were released to the atmosphere, ocean and land, respectively, $\mathrm{CO}_{2}$.earth [23].

\section{ANTHROPOCENE, BIO-CAPACITY AND HUMAN EXISTENCE: THE NEXUS}

It may be concluded that anthropocentric greenhouse gas (GHG) emissions are the main cause of global warming. Indeed, the Fourth Assessment Report of the Intergovernmental Panel on Climate Change (IPCC) stated clearly that "most of the observed increase in global average temperatures since the mid-20th century is very likely due to the observed increase in anthropogenic GHG concentrations' IPCC [24], p. 39. It further revealed that global warming has led to increases in 'global average air and ocean temperatures, widespread melting of snow and ice, and rising global mean sea level.' IPCC [24], p. 30. Certainly, rising temperatures and climate change in part have contributed to the degradation of the bio-capacity of the ecosystems to protect our physical environment from the increased threat of extreme heat, rain, storms, drought and flood. It is worth noting that human-induced environmental changes including anthropocentric GHG emissions have resulted in the bio-degradation of some $60 \%$ of the global life-support ecosystems see, for example, MEA [25]. The consequence is that the bio-capacity of ecosystems have been profoundly affected in their ability to provide the necessary services to support human long-term existence due to the increased likelihood of extreme events such as heat wave, heavy precipitation, severe drought and extreme flood (Table 2).

Global warming tends to intensify the hydrological cycle leading to extreme events. Hydrological cycle refers to the cycle of fresh water evaporating from the oceans, raining out over land and water running back into the sea. At warmer temperatures, the atmosphere can hold more water vapour, so more water is available to fall back to the land when it rains, thus setting the stage for more extreme rainfall patterns followed by severe flooding in many parts of the Asian region, UNEP [26], Table 2. The atmosphere's water-holding capacity increases by about 4 percent for every $1^{\circ} \mathrm{F}\left(0.6^{\circ} \mathrm{C}\right)$ rise in temperature, Union of Concerned Scientists [27]. Meanwhile, in many parts of Africa, Australia and New Zealand, global warming is expected to reduce levels of rainfall. Furthermore, increased evaporation in these regions also causes drier conditions or drought, UNEP [26]. The destructive impacts of GHG emissions are summarised in Table 2.

Also, global warming which causes drought poses a serious threat to all four dimensions of food security, namely, food availability, food accessibility, food utilization and food systems stability. Estimates vary, but for every $1{ }^{\circ} \mathrm{C}\left(1.8^{\circ} \mathrm{F}\right)$ warming, the yields for the world's major grain crops including corn, soybean, rice and wheat are expected to be reduced by about $10 \%$, Halweil [28], Henson [29]. The drop in agricultural yields worsens hunger, putting millions of 
Table 2: Impacts of greenhouse gas emissions.

\begin{tabular}{l} 
Impacts \\
\hline \\
Arctic air tempera- \\
tures: increased by \\
about $5^{\circ} \mathrm{C}$ in the \\
20th century (10 \\
times faster than \\
the global-mean \\
surface tempera- \\
ture)
\end{tabular}

Arctic sea-surface temperatures: increased by $1^{\circ} \mathrm{C}$ over the past 20 year

Spring and summer sea-ice cover in the Northern Hemisphere decreased by about 10 to $15 \%$ from the 1950s to the year 2000

\section{Environmental consequences \\ Examples}

(i) More and more intense rainfall patterns in many mid- to high-latitude land areas in the Northern Hemisphere, (ii) Declining rainfall in the tropics and subtropics in both the Northern and Southern hemispheres with abnormal rainfall patterns (heavy and extreme), leading to widespread flloods and soil erosion, (iii) more extreme rainstorms

(i)Between 1998 and 2004, Europe suffered over 100 major damaging floods, including the catastrophic floods along the Danube and Elbe rivers in summer 2002. Since 1998 floods in Europe have caused some 700 deaths, (ii) the Yangtze floods of 1998 in China (More than 4,100 people were killed, 13.8 million were left homeless, and flooding disasters have become entirely predictable annual events, (iii) the Mozambican flood of 2000 (worsened by two cyclones caused 800 deaths and affected almost 2 million people), (vi) the Algeria flood of 2001 (led to 800 deaths), (vii) Flood in northwest Pakistan in 2010 killed 1,752 people (vii) frequent floods in other Asian countries, especially Southeast Asian countries, namely the Philippines, Indonesia, Malaysia, Thailand, Vietnam, and Cambodia.

(Note: flooding is the most prevalent disaster in North Africa, the second most common in East, South and Central Africa, and the third most common in West Africa)

(i) The total available water of the African large catchment basins of Niger, Lake Chad and Senega has decreased by 40 to $60 \%$. (ii) East Africa's drought between 2011 and mid-2012 (claimed to be to the worst drought in 60 years) (iii) annual rainfall, runoff and soil moisture in southern, northern and western Africa have declined leading to increased summer drying and the associated risk of drought (iv) increased evaporation in Australia and New Zealand lead to drier conditions, with a higher probability of drought (v) decreasing trend of rainfall total as well as its rainfall distribution Philippines from 1960 to 2010 
186 Environmental and Economic Impact on Sustainable Development

Table 2: (Continued)

\begin{tabular}{|c|c|c|}
\hline Impacts & $\begin{array}{l}\text { Environmental } \\
\text { consequences }\end{array}$ & Examples \\
\hline $\begin{array}{l}\text { Sea-ice extent in } \\
\text { the Nordic seas has } \\
\text { shrunk by } \\
30 \% \text { over the last } \\
130 \text { years }\end{array}$ & \multirow{4}{*}{$\begin{array}{l}\text { Heat waves or extreme } \\
\text { heat events 'have become } \\
\text { as much as } 10 \text { times more } \\
\text { likely due to the current } \\
\text { cumulative effects of } \\
\text { human-induced climate } \\
\text { change'(Herring et al., } \\
\text { 2014, p.S82) }\end{array}$} & \multirow{4}{*}{$\begin{array}{l}\text { (i) The Chicago heat wave of } 1999 \\
\text { resulted in at least } 80 \text { deaths, } \\
\text { (ii) European heat wave of } 2003 \text { killed } \\
\text { more than } 80,000 \text { people across Europe } \\
\text { (the deadliest in world history), } \\
\text { (iii) } 2010 \text { Japanese heat wave killed } \\
1718 \text { people, (iv) Indian heat wave of } \\
2015 \text { with temperatures hit } 48^{\circ} \mathrm{C} \\
\left(118^{\circ} \mathrm{F}\right) \text { in some cities, killing } 2,330 \\
\text { people (5th deadliest in the world his- } \\
\text { tory), (v) Pakistan heat wave of } 2015 \\
\text { killed more than } 800 \text { people }\end{array}$} \\
\hline $\begin{array}{l}\text { Arctic sea-ice } \\
\text { thickness declined } \\
\text { by about } 40 \% \text { dur- } \\
\text { ing late summer } \\
\text { and early autumn } \\
\text { in the last three } \\
\text { decades of the } \\
20 \text { th century } \\
\text { Warming of waters } \\
\text { or surface waters } \\
\text { in the Southern and } \\
\text { Arctic Ocean }\end{array}$ & & \\
\hline $\begin{array}{l}\text { Average global sea } \\
\text { level: increased by } \\
8 \text { inches between } \\
1880 \text { and } 2009\end{array}$ & & \\
\hline $\begin{array}{l}\text { Dramatic disap- } \\
\text { pearance of the } \\
\text { glaciers on Mount } \\
\text { Kilimanjaro }\end{array}$ & & \\
\hline
\end{tabular}

Note: compiled by the author from various sources

lives, especially the world's poor in the African region, at risk, Guzma [30], and USDA [31]. For example, drought in the Horn of Africa has affected more than 13 million people due to food insecurity, hunger and malnutrition, IFRC [36].

It is by now clear that human alteration of the carbon cycle has reached a critical stage. Human activities have become so pervasive that they are pushing the Earth chaotically into a much warmer, wetter, stormier state, affecting the core of human long-term existence. The Anthropocene changes in the earth system represent a profound shift in the relationship between humans and nature in that the former have ascended to biospheric supremacy as the supreme geological force distinctly separate from and ethically superior to the rest of the natural systems. This anthropocentric dimension of environmental value system frames the worldview that humans are the master or conquerors of nature, subduing it for their own instrumental purposes. Natural resources are said to be instrumentally valuable if they serve as means to some human end. Thus, natural systems that are of potential use to humans can be a 'resource' to be instrumentally exploited, often in an unsustainable way, resulting in degradation. 
Needless to say, it is this anthropocentric value system that has, for the past 40 years, hampered the continuous global call for greater efforts for environmental conservation. The massive transformation of our planetary system at such an unprecedented rate calls for a more profound ethical engagement with nature. We now proceed to examine the ethical philosophy of environmental conservation and its relationship to sustainable resource use and management.

\section{HUMAN BEINGS AND ECOSYSTEM HEALTH: THE ETHICAL CONNECTION}

Unrestrained human activities have changed most ecosystems, threatening their bio-capacity to provide the required life-supporting services to sustain human long-term survival. Indeed, human beings are the most powerful force of environmental modification and ecological impoverishment, and only human beings are capable of solving these problems. The way forward is for us to dismantle our anthropocentric ethic of environment and to build a common future in harmony with the environment via a moral and ethical engagement with nature. It may well be that thinking morally or ethically about the natural environment can influence human beings' attitudes to support protection or conservation of the holistic natural entities such as ecosystems.

Many of the environmental protective policies often involve ethical questions. In other words, in our economic use of nature, human environmental value judgments influence individual ethical behaviour and government policy towards nature. The question here is how to define our place in nature, and what ethical principles should shape humans' environmental attitudes. Technically speaking, environmental policies aiming at protecting the ecological health of ecosystems must express values based on a 'non-anthropocentric moral system'.

To begin with, the anthropocentric value system may be contrasted with the biocentric worldview which considers the moral relations between humans and all other living things, Taylor [33]. Biocentrism holds the beliefs that humans are part of the earth's community and all species are part of a system of interdependence. It also construes that humans are not inherently superior to other living things. Rather, all living things have equal and inherent worth, that is, they are intrinsically valuable. Biocentric ethics may thus be defined as any theory that assigns intrinsic value or moral norms to life, including animals or plants, Rolston [34]. Biocentrism is a life-centre system of environmental ethics, with its overall aim as avoiding an attitude of dominance over nature, and to live in harmony with all individual living things on earth, as all are worthy of moral consideration, Taylor [33]. However, biocentrism is a kind of ethics of individualism and may not be adequate to establish a moral sense of duty to the earth as a whole.

An alternative is to embrace the ecocentric world view, which incorporates biocentrism into its philosophical field of environmental ethics. Ecocentrism which is rooted in ecology advocates the protection of the ecological health of the ecosystems as a whole. In other words, moral consideration is extended to the entire ecosystem rather than to an individual entity as in biocentrism. Ecocentrics see themselves as a part of nature, rather than being in control of it, and assume moral responsibility towards nature, focusing on how to preserve its ecological integrity and stability see, for example, Leopold [35]. The positive relationship between these philosophical and ethical aspects of environmentalism and sustainable environmental management has been verified based on extensive field studies conducted between 2007 and 2011 with the indigenous people in the Malaysian state of Sarawak located in Borneo, Choy [36].

It may be said that many of today's environmental problems are basically caused by the lack of ethics on the part of economic agents when optimizing the economic use of nature. 
188 Environmental and Economic Impact on Sustainable Development

That said, man-nature relationship is, to a large extent, dominated by economic motives, entailing little obligation for environmental protection. It is only through the cultivation of the kind of ethics that aims at a harmonious coexistence between humanity and nature can we hope to halt further transgressions of the earth's planetary boundaries. This necessarily involves a basic change in our value systems based on ecosystem bio-capacity and ethical principles of resource use and management.

\section{CONCLUDING REMARKS}

This article demonstrates that 'ecosystem health' is inextricably linked to long-term human existence. Today, the human ecological footprint is growing at an unprecedented speed and scale, leading to extensive damage of the earth's ecosystems and its bio-capacity to provide the necessary life-supporting services to sustain human long-term existence. The importance of environmental ethics is affirmed as an indispensable moral philosophy for engagement with the environmental problems facing us today. More specifically, biodiversity conservation and environmental ethics go hand in glove, and it is only through the extension of environmental ethics to nature that we can avoid crossing the planetary tipping point that could lead to abrupt or irreversible ecological destruction.

It has also become increasingly clear that global environmental protection initiatives as preached by the United Nations are only part of what is needed to promote ecological sustainability. With 'Anthropocene' looming to lock the earth and our future generations into an unsustainable epoch and with human beings remaining a major geological force dominating the planet for many millennia, the way forward is to initiate, inculcate and cultivate a harmonious human-environment relationship based on the ethics of human-nature relations.

\section{ACKNOWLEDGEMENTS}

This work was supported by the MEXT*-Supported Program for the Strategic Research Foundation at Private University, 2014-2018 (*Ministry of Education, Culture, Sports, Science and Technology, Japan).

\section{REFERENCES}

[1] Schaefer, F., Luksch, U., Steinbach, N., Cabeça, J. \& Hanaue, J., Ecological footprint and biocapacity the world's ability to regenerate resources and absorb waste in a limited time period, European Communities: Luxembourg, 2006.

[2] Sanders, N.R. \& Wood, J.D., Foundations of Sustainable Business: Theory, Function, and Strategy, John Wiley \& Son: Hoboken, NJ, 2015.

[3] Mills, L.S., Soulé, M.E. \& Doak, D.F., The keystone-species concept in ecology and conservation. BioScience, 43(4), pp. 219-224, 1993. http://dx.doi.org/10.2307/1312122

[4] WHO, Ecosystems and Human Well-being. Health Synthesis, World Health Organisation (WHO): Geneva, Switzerland, 2005.

[5] Nellemann, C., Corcoran, E., Duarte, C.M., Valdés, L., De Young, C., Fonseca, L. \& Grimsditch, G. (eds), Blue carbon. A Rapid Response Assessment. United Nations Environment Programme: GRID-Arendal, 2009.

[6] WWF. Forests of Borneo. Forest Area Key Facts \& Carbon Emissions from Deforestation World Wildlife Fund (WWF), Indonesia, 2007.

[7] Gewin, V., Natural defences can sharply limit coastal damage. Nature, 2013, Available at: http://www.nature.com/news/natural-defences-can-sharply-limit-coastaldamage-1.13380 
[8] Hardman-Mountford, N., Litt, E., Mangi, S., Dye, S., Schuster, U., Bakker, D. \& Watson, A., Ocean uptake of carbon dioxide (CO2), MCCIP Briefing Notes. Marine Climate Change Impacts Partnership (MCCIP): United Kingdom, 2009.

[9] Giering, S.L.C., Sanders, R., Lampitt, R.S., Anderson, T.R., Tamburini, C., Boutrif, M., Zubkov, M.V., Marsay, C.M., Henson, S.A., Saw, K., Cook, K. \& Mayor, D.J., Reconciliation of the carbon budget in the ocean's twilight zone. Nature, 507, pp. 480-483, Available at: http://www.nature.com/nature/journal/v507/n7493/full/nature13123.html http://dx.doi.org/10.1038/nature13123

[10] Sabine, C.L. \& Feely, R.A., The ocean sink for carbon dioxide. Greenhouse Gas Sinks, eds. D. Reay, N. Hewitt, J. Grace \& K. Smith, CABI Publishing: Oxfordshire, UK, pp. 31-49, 2007. http://dx.doi.org/10.1079/9781845931896.0031

[11] Riebeek, H., The Ocean's Carbon Balance, The Earth Observatory: U.S.A., 2008. Available at: http://earthobservatory.nasa.gov/Features/OceanCarbon/

[12] Toseland, A., Daines, S.J., Clark, J.R., Kirkham, A., Strauss, J., Uhlig, C., Lenton, T.M., Valentin, K., Pearson, G.A., Moulton V. \& Mock T., The impact of temperature on marine phytoplankton resource allocation and metabolism. Nature Climate Change, $\mathbf{3}$, pp. 979-984, 2013, Available at http://www.nature.com/nclimate/journal/v3/n11/pdf/ nclimate1989.pdf http://dx.doi.org/10.1038/nclimate1989

[13] Guinder, V.A. \& Molinero, J.C., Climate change effects on marine phytoplankton. Marine Ecology in a Changing World, eds. A.H. Arias \& M.C. Menendez, CRC Press: Boca Raton, London, New York, pp. 68-90, 2013. http://dx.doi.org/10.1201/b16334-4

[14] Malm, A. \& Hornborg, A., The geology of mankind? A critique of the Anthropocene narrative. The Anthropocene Review, 1(1), pp. 62-69, 2014. http://dx.doi.org/10.1177/2053019613516291

[15] Rockström, J., Steffen, W., Noone, K., Persson, A., Chapin, F.S., Lambin, E., et al., Planetary boundaries: exploring the safe operating space for humanity. Ecology and Society, 14(2), p. 32, 2009, Available at http://www.ecologyandsociety.org/vol14/iss2/ art32/

[16] ESDN, Planetary Boundaries for SD from an international perspectives to national applications. ESDN Quarterly Report N30. European Sustainable Development Network (ESDN), Vienna, Austria, 2013.

[17] Raupach, M.R. \& Canadell, J.G., Carbon and the anthropocene. Current Opinion in Environmental Sustainability, 2, pp. 210-218, 2010. http://dx.doi.org/10.1016/j.cosust.2010.04.003

[18] NOAA. Recent Monthly Average Mauna Loa $\mathrm{CO}_{2}$. National Oceanic and Atmospheric Administration (NOAA), U.S. Department of Commerce, 2016.

[19] CDIAC, Global Carbon Project. Carbon Dioxide Information Analysis Center, (CDIAC), US Department of Energy, 2015, Available at http://cdiac.ornl.gov/GCP/\#http:// www.esrl.noaa.gov/gmd/ccgg/trends/

[20] $\mathrm{CO}_{2}$.Earth 2016, Global Carbon Emissions. $\mathrm{CO}_{2}$.Earth, Canada, 2016. Available at https://www.co2.earth/global-co2-emissions

[21] Hansen, B., History of earth's climate. Dalum Hjallese Debate Club, Denmark, 2013, Available at http://www.dandebat.dk/eng-klima1.htm 
190 Environmental and Economic Impact on Sustainable Development

[22] IEA, $\mathrm{CO}_{2}$. Emission from Fuel Combustion (2015 Edition). International Energy Agency (IEA), OECD Publishing, Paris, 2015.

[23] CO2.earth, Global Carbon Emissions, 2016, Available at https://www.co2.earth/globalco2-emissions?

[24] IPCC, Climate change 2007:synthesis report. Contribution of Working Groups I, II and III to the Fourth Assessment Report of the Intergovernmental Panel on Climate Change (IPCC). IPCC, Geneva, Switzerland, 2007.

[25] MEA, Ecosystems and human well-being: synthesis. Millennium Ecosystem Assessment (MEA), Island Press: Washington, DC, 2005.

[26] UNEP, How will global warming affect my world? A simplified guide to the IPCC's "Climate Change 2001: Impacts, Adaptation and Vulnerability". United Nations Environment Programme (UNEP), Switzerland, 2003.

[27] Union of Concerned Scientists. Extreme wet. 2011, Available at http://www.climatehotmap.org/global-warming-effects/rain-and-snow.html

[28] Halweil, B., The Irony of Climate. World Watch Institute: Washington, DC, 2005.

[29] Henson, R., Warming world: Impacts by a degree. National Academies of Sciences, USA, 2011.

[30] Guzman, A.T., Overheated: The Human Cost of Climate Change. Oxford University Press: U.S.A., 2013.

[31] USDA, Climate Change, Global Food Security, and the U.S. Food System. The U.S. Department of Agriculture (USDA), 2015.

[32] IFRC, Drought in the horn of Africa. Preventing the next disaster. International Federation of Red Cross and Red Crescent Societies (IFRC), Geneva, 2011.

[33] Taylor, P., Respect for nature. A Theory of Environmental Ethics, Princeton University Press: New York, 1986.

[34] Rolston, H., Environmental Ethics: Duties to and Values in the Natural World, Temple University Press: Philadelphia, 1988.

[35] Leopold, A., A Sand County Almanac, Oxford University Press: New York, 1949.

[36] Choy, Y.K., Land ethics from the borneo tropical rain forests in Sarawak, Malaysia: an empirical and conceptual analysis. Environmental Ethics, 36(4), pp. 421-441, 2014. http://dx.doi.org/10.5840/enviroethics201436446 